\title{
Effects of Environment and Nutritional Conditions on mycelial growth of Ganoderma boninense
}

\author{
Shih Hao Tony Peng ${ }^{1 *}$, Chee Kong Yap ${ }^{2}$, Peng Fei Ren ${ }^{3}$, Ee Wen Chai ${ }^{1}$ \\ ${ }^{1}$ All Cosmos Bio-Tech Holding Corporation, Johor 81700, Malaysia. \\ ${ }^{2}$ University Putra Malaysia, Selangor 43400, Malaysia. \\ ${ }^{3}$ Shandong Academy of Agriculture Sciences, Shandong 250100, China.
}

\begin{abstract}
The basal stem rot disease is caused by the soil-borne pathogen, Ganoderma boninense. It is an annihilating and widespread disease in oil palm (Elaeis guineensis Jacq.). The nutritional studies were conducted to know the best sources of carbon and nitrogen, ideal $\mathrm{pH}$ regimes, the best humidity and optimum temperature required for the mycelial growth of $G$. boninense. Out of six carbon sources tested, fructose and glucose proved to be the best carbon sources for the mycelial growth of $G$. boninense. Out of five nitrogen sources tested, ammonium citrate and ammonium nitrate were noticeably found as the best nitrogen sources for the mycelial growth. Studies on different $\mathrm{pH}$ regimes in medium with $83 \%$ potatoes and $75 \%$ lignocellulosic materials revealed that the ideal $\mathrm{pH}$ regimes for the mycelial growth were 4-5. The best humidity for mycelial growth of $G$. boninense was found between $50-60 \%$. It is suitable to grow between 25 and $32{ }^{\circ} \mathrm{C}$, while the optimum temperature is $32{ }^{\circ} \mathrm{C}$. This information can be used as a guideline for Ganoderma's disease prevention study and control strategies in the oil palm plantation in the future.
\end{abstract}

Keywords: Ganoderma's disease, mycelial growth, nutritional conditions, oil palm

\section{INTRODUCTION}

Oil palm (Elaeis guineensis Jacq.) is an important crop plantation widely cultivated throughout Southeast Asia countries. Unfortunately, the industry is badly affected by basal stem rot (BSR) disease which is initiated by the soil-borne pathogen namely Ganoderma boninense (Ho \& Nawawi 1985; Hushiarian et al. 2013). This BSR disease is the most devastating and prevalent disease in oil palm
(Alexander et al. 2017) and has been the root cause for the significant loss of income in Indonesia and Malaysia (Alexander et al. 2017; Fowotade et al. 2019). The oil palm plantations are suffering significant damage of oil palms at the early stages and this has directly decreased the oil yield (Tan et al. 2018). It is therefore, ways of controlling the disease need to be researched and implemented so as to sustain the palm oil industry in this region (Hushiarian et al. 2013).

\footnotetext{
*Corresponding author:

All Cosmos Bio-Tech Holding Corporation, PLO650,

Jalan Keluli, Pasir Gudang Industrial Estate, 81700 Pasir Gudang, Johor, Malaysia.

Email: tonypeng@allcosmos.com
} 
All the fungi have specific nutritional requirement. The mycelial growth of fungi in nature depends on a lot of external and internal factors. These include temperature, humidity, $\mathrm{pH}$, soil structure and the nutrient availability including carbon and nitrogen sources (Lipavska \& Konradova 2004; De paiva neto \& Otoni 2003; Songulashvili et al. 2008; Yassen et al. 2013).

It is well reported in the literature that the growth and multiplication of shoots in vitro during plant tissue culture techniques are affected by many factors such as carbon and nitrogen sources (Mamoun \& Olivier 1991; Panchal \& Raol 2007; Li et al. 2011; Itoo \& Reshi 2014; Lazarević et al. 2016) besides temperature and $\mathrm{pH}$ (Lazarević et al. 2016). Nitrogen and carbon are the indispensable and essential elements, besides others, for the infection, growth and reproduction of the fungi (Lilleskov et al. 2002; Yassen et al. 2013; Daza et al. 2016). The carbon and nitrogen sources greatly affect the growth and establishment of fungi in the field and also in vitro under the laboratory condition (Lilleskov et al. 2002). For example, Papaspyridi et al. (2012) studied the effects of nitrogen and carbon sources on the production of dietary glucans and fibres by $G$. australe and Pleurotus ostreatus while Peng et al. (2016) investigated the effects of mixed carbon sources by using mannose and galactose in $G$. Iucidum. All the above literature pointed to the importance of the optimal nutritional conditions needed by different species of fungus for a variety of beneficial purposes.

From the literature, some preventive treatments to control Ganoderma infection in oil palm have been developed such as using the Ganoderma selective medium (GSM) (Ariffin \& Idris 1992), the GanoCare $^{\mathrm{TM}}$ organic (Idris et al. 2014) and the GanoCare ${ }^{\mathrm{TM}}$ OCSpecial (Idris et al. 2015). However, there is no informa- tion on the nutritional conditions for mycelial growth of $G$. boninense in which the information can be used in formulating the guideline for Ganoderma's disease prevention.

The culture conditions for mycelial growth of Ganoderma have been reported for G. applanatum (Jo et al. 2009; Jeong et al. 2009). Goh et al. (2016) studied the influence of different medium components (glucose, sucrose and fructose) on the growth of different Ganoderma species including $G$. boninense, $G$. lingzhi and $G$. australe. However, specific culture conditions for $G$. boninense has not been reported in the literature. Therefore, the aim of the present study is to evaluate and determine the optimal environment and nutritional conditions for mycelial growth of $G$. boninense.

\section{MATERIALS AND METHODS}

The strain used on the present study was $G$. boninense isolated from Malaysia's oil palm plantation.

\section{Determination of the Optimum pH}

The ingredients for this study included potato, glucose, hydrochloric acid, sodium hydroxide and agar. An amount of $1000 \mathrm{~mL}$ of nutrient solution was prepared from $200 \mathrm{~g}$ of potatoes (83\%), $20 \mathrm{~g}$ of glucose $(8.3 \%)$ and $21 \mathrm{~g}$ of agar (8.7\%). An amount of $900 \mathrm{~mL}$ medium was prepared and poured into separate conical flasks; each flask contained $150 \mathrm{~mL}$ of medium. Medium in the conical flask was adjusted to $\mathrm{pH} 1,2,3,4,5,6,7,8,9,10,11,12,13$ and 14 by using hydrochloric acid and sodium hydroxide. Each $\mathrm{pH}$ has 4 replicates. The medium was autoclaved at $121^{\circ} \mathrm{C}$ for 40 minutes. After the medium was cooled down to $50{ }^{\circ} \mathrm{C}$, it was poured into a petri dish under sterile conditions. A $0.5 \mathrm{~cm} \times 0.5 \mathrm{~cm}$ of $G$. boninense was inoculated and they 
were incubated at $25{ }^{\circ} \mathrm{C}$. Mycelial growth of the fungus was observed for every 48 hours.

Since medium with too low $\mathrm{pH}$, the agar could not completely dissolve, lignocellulosic materials were used as a medium for $G$. boninense. This experiment is to investigate whether the mycelia of Ganoderma boninense isolated from oil palm plantation able to survive in overly acidic and overly basic condition.

The ingredients for this study included lignocellulosic materials, wheat bran and glucose. The medium formulation consisted of $75 \%$ lignocellulosic materials, $24 \%$ wheat bran, and $1 \%$ glucose. A total of $30 \mathrm{~g}$ lignocellulosic materials, $9.6 \mathrm{~g}$ wheat bran, $0.4 \mathrm{~g}$ glucose were weighed and they were mixed evenly in a ratio of 1:1.4 (1 part of material to 1.4 part of water). The $\mathrm{pH}$ of the medium was adjusted using hydrochloric acid and sodium hydroxide and it was put into an $18 \mathrm{~mm} \times 18 \mathrm{~mm}$ test tube. The medium occupied half of the test tube space. The steps above were repeated to prepare medium of $\mathrm{pH} 1,2,3$, 4, 11, 12, 13 and 14. Each $\mathrm{pH}$ value has 7 replicates. Test tubes were filled up with different $\mathrm{pH}$ values substrates. The media were autoclaved at $121{ }^{\circ} \mathrm{C}$ for 2 hours. Ganoderma boninense was inoculated after the tube was cooled down. The test tubes were then incubated at $25^{\circ} \mathrm{C}$ for 14 days. Mycelial growth of the fungus was observed for every 48 hours.

\section{Determination of Best Carbon Source}

The ingredients for this in vitro study included potato, yeast extract, glucose, lactose, fructose, maltose, sucrose, soluble starch and agar. For the use of glucose as a carbon source, $1000 \mathrm{~mL}$ of nutrient solution was prepared from $200 \mathrm{~g}$ of potatoes, $5 \mathrm{~g}$ of yeast extract, $20 \mathrm{~g}$ of glucose and $21 \mathrm{~g}$ of agar. An amount of $1500 \mathrm{~mL}$ medium was later prepared. For prepara- tion of other carbon sources, glucose in the medium was replaced with an equal amount of lactose, fructose, maltose, sucrose and soluble starch, respectively. An amount of $150 \mathrm{~mL}$ was prepared for each carbon source. The medium was autoclaved at $121{ }^{\circ} \mathrm{C}$ for 30 minutes. Each carbon source has 4 replicates and they were inoculated with $G$. boninense. The culture plates were incubated at $25{ }^{\circ} \mathrm{C}$ and the mycelium growth were observed for every 48 hours.

\section{Determination the Best Nitrogen Source}

The nitrogen sources can be divided into: a inorganic sources namely ammonium nitrate and ammonium citrate; and b organic sources namely beef extract, peptone and urea. The ingredients for this in vitro study included potato, ammonium nitrate, ammonium citrate, beef extract, peptone, urea and agar. For the use of peptone as a nitrogen source, an amount of $1000 \mathrm{~mL}$ of nutrient solution was prepared from $200 \mathrm{~g}$ of potatoes, $5 \mathrm{~g}$ of peptone, $20 \mathrm{~g}$ of glucose and $21 \mathrm{~g}$ of agar. For preparation of other nitrogen sources, peptone in the medium was replaced with an equal amount of ammonium nitrate, ammonium citrate, beef extract and urea, respectively. An amount of $150 \mathrm{~mL}$ was prepared for each nitrogen source. The medium was autoclaved at $121{ }^{\circ} \mathrm{C}$ for 30 minutes. Each nitrogen source has 4 replicates and they were inoculated with $G$. boninense. The culture plates were incubated at $25^{\circ} \mathrm{C}$ and the mycelium growth were observed for every 48 hours.

\section{Determination of the Optimum Temperature}

The ingredients in this study included potato, yeast extract, glucose, agar and wheat bran. An amount of $1000 \mathrm{~mL}$ of nutrient solution was prepared from 
$200 \mathrm{~g}$ of potatoes, $5 \mathrm{~g}$ of yeast extract, $20 \mathrm{~g}$ of glucose and $21 \mathrm{~g}$ of agar and $50 \mathrm{~g}$ of wheat bran. According to the formula, $900 \mathrm{~mL}$ of medium was prepared and poured into 6 conical flasks; each conical flask contained $150 \mathrm{~mL}$ of medium. The medium was autoclaved at $121{ }^{\circ} \mathrm{C}$ for 40 minutes. After the medium was cooled down to $50{ }^{\circ} \mathrm{C}$, it was poured into a petri dish under a sterile condition. An area of $0.5 \mathrm{~cm} \times 0.5 \mathrm{~cm}$ of $G$. boninense was inoculated and it was incubated at $20^{\circ} \mathrm{C}, 25^{\circ} \mathrm{C}$, $30{ }^{\circ} \mathrm{C}, 35^{\circ} \mathrm{C}$ incubator, respectively. Each temperature has 4 replicates. Mycelial growth was observed in every 48 hours.

\section{Determination of the Best Humadity}

The substrate formula used in this study was: $75 \%$ lignocellulosic materials, $23 \%$ bran, $1 \%$ glucose, $1 \%$ lime. A total of $30 \mathrm{~g}$ of lignocellulosic materials, $9.2 \mathrm{~g}$ of wheat bran, $0.4 \mathrm{~g}$ of glucose and $0.4 \mathrm{~g}$ of lime were mixed evenly with a mix ratio 1:1 (1 part of material to 1 part of water). The substrate was then put in a $20 \mathrm{~cm} x-$ $200 \mathrm{~cm}$ test tube, which occupied half of the test tube space. The steps above were repeated for the mixture ratio of $1: 1,1: 1.2$, $1: 1.5,1: 1.9$ and $1: 2.4$ in order to obtain the substrate's humidity of $50,55,60,65$ and $70 \%$. Test tubes filled with different mixture ratios substrates were autoclaved at $121{ }^{\circ} \mathrm{C}$ for 2 hours. Each humidity has 5 replicates of test tube. Later, G. boninense was inoculated after the tube was cooled down. The test tubes were then incubated at $25^{\circ} \mathrm{C}$ for 14 days, the mycelial growth was observed in every 48 hours.

\section{Statistical Analysis}

By using a statistical software (Statsoft STATISTICA version 10 for Windows), inter treatment differences of each parameter in the different nutritional conditions of mycelial growths were analysed using the Post-hoc test (Student-Newman-Keuls) to see if there was any significant difference at $\mathrm{P}<0.05$

\section{RESULTS AND DISCUSSION}

\section{Effects of pH Regimes}

The observational mycelial growths of G. boninense in medium with $83 \%$ potatoes, under $\mathrm{pH}$ regimes of 5, 6 and 7 , are shown in Figure 1 while those under $\mathrm{pH}$ regimes of 8,9 and 10 are presented in Figure 2. The effects of different $\mathrm{pH}$ regimes (5 to 10) on the mycelial growth of $G$. boninense are presented in Table 1. From Table 1, it shows that mycelia of G. boninense are able to grow in medium with $83 \%$ potatoes, under the $\mathrm{pH}$ regimes of $5,6,7,8,9$ and 10. However, when $\mathrm{pH}$ of medium was adjusted to $1,2,3,4,11$, 12,13 and 14, the agar could not dissolve completely, therefore no mycelial growths of $G$. boninense were observed for the above eight regimes of $\mathrm{pH}$ values.

The observational mycelial growths of G. boninense in medium with $75 \%$ lignocellulosic materials, under acidic conditions, $\mathrm{pH}$ regimes of $1,2,3$ and 4 , are shown in Figure 3 while those under alkaline conditions, $\mathrm{pH}$ regimes of 11,12 , 13 and 14, are presented in Figure 4. The effect of different $\mathrm{pH}$ values on the mycelia growth of $G$. boninense in medium with $75 \%$ lignocellulosic materials are presented in Table 2. From Table 2, $\mathrm{pH}$ 1 and 2 resulted in no sign of mycelium growth while $\mathrm{pH} 4$ showed best mycelium growth rate with mycelia did not turn to yellow color. Growth rates in $\mathrm{pH} 3,11,12$, 13 and 14 did show mycelium growth with mycelia colors ranging from obviously in yellow color to slight turn to yellow color. This shows that mycelia of $G$. boninense are able to grow in medium with $83 \%$ potatoes, under the $\mathrm{pH}$ regimes of $3,11,12$, 13 and 14, with the best growth rate found in $\mathrm{pH} 4$. 


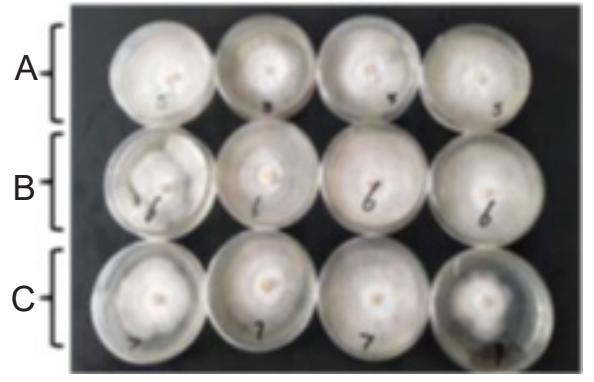

Figure 1 The observational mycelial growths of Ganoderma boninense in medium with $83 \%$ potatoes, under $\mathrm{pH}$ regimes of $\mathrm{a} 5, \mathrm{~b} 6$ and $\mathrm{c} 7$.

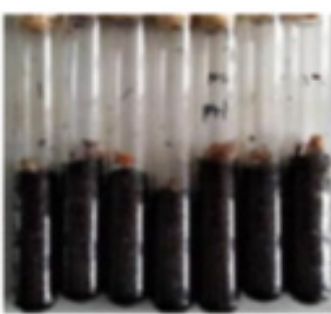

a $\mathrm{pH} 1$

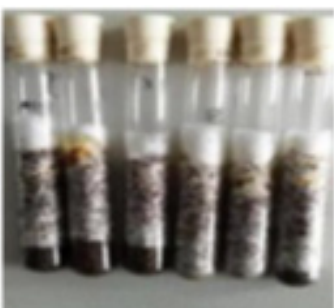

$\mathrm{c} \mathrm{pH} 3$

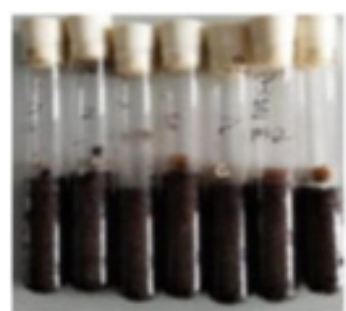

b pH 2

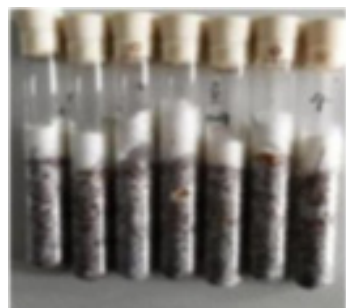

$\mathrm{d} \mathrm{pH} 4$
Figure 3 The observational mycelial growths of Ganoderma boninense in medium with $75 \%$ lignocellulosic materials under acidic conditions, $\mathrm{pH}$ regimes of a 1, b 2, c 3, c one replicate is not available and $\mathrm{d} 4$.

Table 1 The effects of different $\mathrm{pH}$ regimes on the mycelial growth (mean $\pm \mathrm{SE}, \mathrm{cm}$ ) of Ganoderma boninense in medium with $83 \%$ potatoes

\begin{tabular}{ccccc}
\hline $\begin{array}{c}\mathrm{pH} \\
\text { value }\end{array}$ & Day 2 & Day 4 & Day 6 & $\begin{array}{c}\text { Mycelial } \\
\text { density }\end{array}$ \\
\hline 5 & $1.67 \pm 0.07^{\mathrm{e}} 4.30 \pm 0.01^{\mathrm{b}}$ & $7.65 \pm 0.05^{\mathrm{b}}$ & +++ \\
6 & $1.55 \pm 0.05^{\mathrm{d}} 4.45 \pm 0.05^{\mathrm{d}}$ & $7.55 \pm 0.05^{\mathrm{b}}$ & ++ \\
7 & $1.28 \pm 0.08^{\mathrm{ab}} 3.78 \pm 0.01^{\mathrm{a}}$ & $6.53 \pm 0.02^{\mathrm{a}}$ & ++ \\
8 & $1.43 \pm 0.03^{\mathrm{c}} 4.40 \pm 0.01^{\mathrm{cd}}$ & $7.80 \pm 0.01^{\mathrm{c}}$ & ++ \\
9 & $1.20 \pm 0.01^{\mathrm{a}} 4.55 \pm 0.03^{\mathrm{e}}$ & $7.93 \pm 0.03^{\mathrm{d}}$ & ++ \\
10 & $1.30 \pm 0.01^{\mathrm{b}} 4.35 \pm 0.04^{\mathrm{bc}}$ & $7.83 \pm 0.03^{\mathrm{c}}$ & ++ \\
\hline
\end{tabular}

"Note: The more "+", the higher mycelial density Values sharing a common letter in the post hoc column are not significantly different $(P>0.05)$.

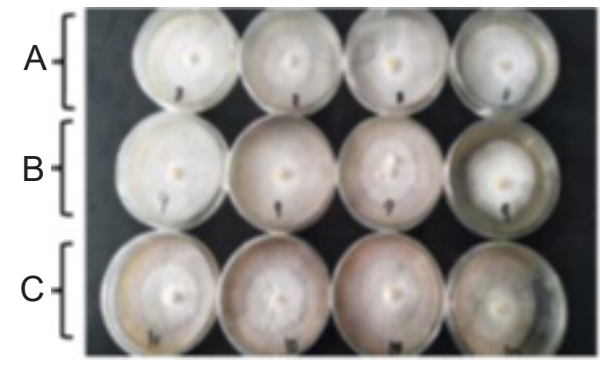

Figure 2 The observational mycelial growths of Ganoderma boninense in medium with $83 \%$ potatoes, under $\mathrm{pH}$ regimes of $\mathrm{a} 8, \mathrm{~b} 9$ and $\mathrm{c} 10$.

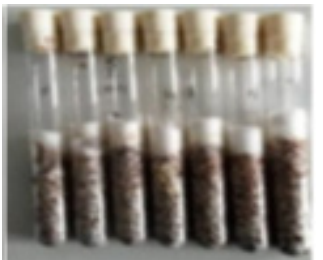

a pH 11

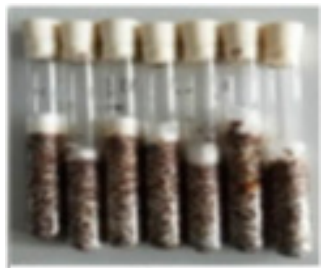

$\mathrm{c} \mathrm{pH} 13$

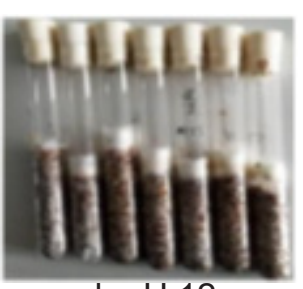

b pH 12

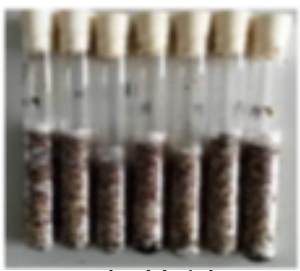

$\mathrm{d} \mathrm{pH} 14$
Figure 4 The observational mycelial growths of Ganoderma boninense in medium with $75 \%$ lignocellulosic materials under alkaline conditions, $\mathrm{pH}$ regimes of a 11, b 12, c 13 and d 14 .

Table 2 Effect of different $\mathrm{pH}$ values on the mycelia growth of Ganoderma boninense in medium with $75 \%$ lignocellulosic materials

\begin{tabular}{ccc}
\hline $\mathrm{pH}$ values & Mycelia color & Growth rate \\
\hline 1 & - & - \\
2 & - & - \\
3 & ++ & + \\
4 & +++ & +++ \\
11 & ++ & ++ \\
12 & + & ++ \\
13 & + & ++ \\
14 & + & + \\
\hline
\end{tabular}

Note:

Mycelial color: "-" mycelia did not grow; "+" mycelia obviously in yellow color; "++" mycelia slightly turn to yellow color; "+++" mycelia did not turn to yellow color Growth rate: The more "+", the better mycelial growth. 
Studies on different $\mathrm{pH}$ regimes in medium with $83 \%$ potatoes and $75 \%$ lignocellulosic materials, revealed that the ideal $\mathrm{pH}$ for the mycelial growth were 4-5. Deshmukh et al. (2012) also reported that the optimum $\mathrm{pH}$ for the fungus $C$. gloeosporioides to produce the maximum dry mycelial weight and sporulation were at $\mathrm{pH} 5.5$ and $\mathrm{pH} 6.5$ in liquid media, respectively. Favorable mycelial growth of $G$. boninense was obtained at the $\mathrm{pH}$ range of 5 to 9 (Table 1). Therefore, the results indicated that $G$. boninense can grow at broad range of $\mathrm{pH}$, from $\mathrm{pH} 5$ to 10. This result also indicated that different $G$. boninense prefer different $\mathrm{pH}$ values tending toward neutrality.

The present result was supported by mycelial growth of $G$. Iucidum can be observed at the $\mathrm{pH}$ range of 5 to 9 . Jonathan et al. (2004) and Fasola et al. (2007) obtained very good mycelial growth of Volvariella esculenta and $V$. speciosa, respectively, over a wide range of $\mathrm{pH}$ regimes but optimum growth was obtained at $\mathrm{pH}$ 6. Likewise Adejoye et al. (2007) also reported Schizophyllum commune exhibited a favorable growth at $\mathrm{pH} 5.5$ while Akinyele and Adetuyi (2005) reported that $\mathrm{pH}$ range for the mycelial growth of $V$. volvacea was between 5.5 and 8.5. All of their results suggested that mushrooms may have a broad $\mathrm{pH}$ range for their favorable mycelial growth.

\section{Effect of Carbon Sources}

The observational mycelial growths of $G$. boninense under lactose, soluble starch and fructose as carbon sources are given Figure 5 while those under maltose, glucose and sucrose as carbon sources are presented in Figure 6. The effects of different carbon sources on the mycelial growth of $G$. boninense are shown in Table 3. From Table 3, among all the carbon sources, the order of mycelial

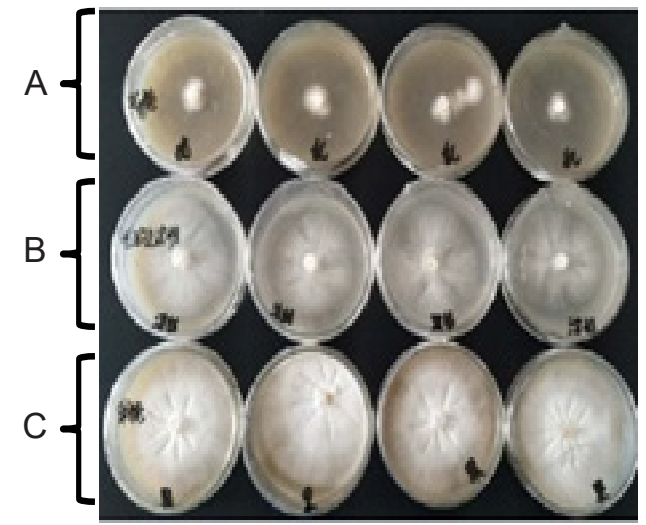

Figure 5 The observational mycelial growths of a Ganoderma boninense under lactose, b soluble starch and c fructose as carbon sources.

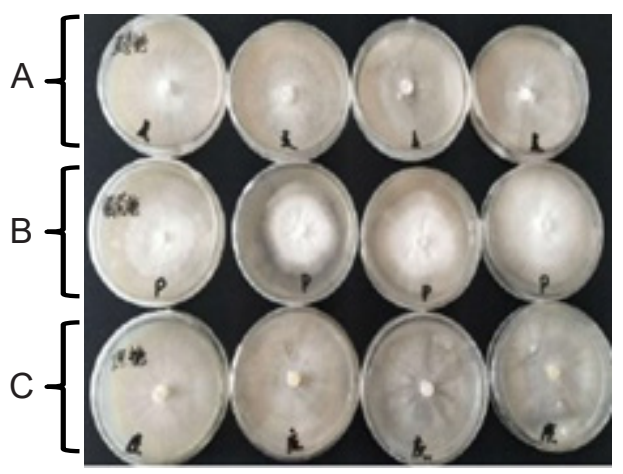

Figure 6 The observational mycelial growths of a Ganoderma boninense under maltose, a glucose and c sucrose as carbon sources.

Table 3 The effects of different carbon sources on the mycelial growth (mean $\pm \mathrm{SE}, \mathrm{cm}$ ) of Ganoderma boninense

\begin{tabular}{|c|c|c|c|c|}
\hline $\begin{array}{l}\text { Carbon } \\
\text { sources }\end{array}$ & Day 2 & Day 4 & Day 6 & $\begin{array}{c}\text { Mycelial } \\
\text { growth }\end{array}$ \\
\hline Glucose & $2.10 \pm 0.02^{b}$ & $4.30 \pm 0.03^{b}$ & $7.00 \pm 0.02^{b c}$ & c $\quad+++$ \\
\hline Maltose & $2.80 \pm 0.02$ & $6.00 \pm 0.02^{d}$ & $8.00 \pm 0.03^{d}$ & ++ \\
\hline Fructose & $2.50 \pm 0.01$ & $5.40 \pm 0.02^{c}$ & $7.50 \pm 0.04^{c}$ & +++ \\
\hline Sucrose & $2.30 \pm 0.03^{b}$ & $5.00 \pm 0.03^{c}$ & $7.60 \pm 0.02^{c}$ & + \\
\hline Lactose & $1.80 \pm 0.01^{a}$ & $1.80 \pm 0.02^{a}$ & $1.80 \pm 0.01^{a}$ & + \\
\hline $\begin{array}{l}\text { Soluble } \\
\text { starch }\end{array}$ & $1.90 \pm 0.01^{\circ}$ & $4.10 \pm 0.02^{b}$ & $6.50 \pm 0.03^{b}$ & ++ \\
\hline
\end{tabular}

* Note: The more "+", the better mycelial growth Values sharing a common letter in the post hoc column are not significantly different $(P>0.05)$.

growths were observed as glucose and fructose>maltose and soluble starch>sucrose and lactose. This indicated noticeably that 
glucose and fructose are better carbon sources for mycelial growth of G. boninense.

Out of six carbon sources tested, fructose and glucose had been found as the best for the mycelial growth. This indicated noticeably that fructose and glucose are better carbon sources for mycelial growth of $G$. boninense. Sangeetha \& Rawal (2008) reported that mannitol was found to be the best source of carbon for the growth and sporulation of the Colletotrichum gloeosporioides (mango disease), followed by fructose and sucrose. According to Bhojwani and Rajdan (1996), glucose and fructose can hold up for the growth of some tissues during tissue culture. The carbon sources of the medium can supply energy and uphold the osmotic potential (De paiva neto \& Otoni 2003). Based on different carbon sources on in vitro micropropagation of Oxalis corniculata, Swetha Prasuna and Srinivas (2016) reported that fructose was the best carbon source with maximum increase of shoot multiplication. Panchal and Raol (2007) reported that mannitol was found as the best carbon source for the in vitro vegetative growth of Fusarium moniliforme isolated from wilted sugar cane fields. In comparison to that reported by Deshmukh et al. (2012), they reported that starch and xyllose were the best carbon sources for the growth and sporulation of C. gloeosporioides, followed by glucose and sucrose. All the reviewed information above indicated different species of fungus has the different optimal carbon sources for the mycelial growth of the fungus.

Dextrin was the best carbon source for mycelial growth of G. lucidum. However, found sorbitol lactose and glucose showed slow level of mycelial growth in G. lucidum. However, in case of IUM 938 strain of $G$. Iucidum, optimum mycelial growth was found on fructose, agreeing with the present result for $G$. boninense.
Chandra and Purkayastha (1977) had previously reported that most of the tropical edible macrofungi were in favor of utilizing glucose than other carbon sources. The preference of glucose over other carbon compounds may be due to the fast metabolization of glucose by the fungi to produce cellular energy easily (Garraway \& Evans 1984). Griffin (1994) suggested that mannose and fructose are the most commonly utilized sugars after glucose. Those results are partially similar to our findings, but they showed that mycelial density in all carbon sources is thin where our result is opposite.

\section{Effect of Nitrogen Sources}

The observational mycelial growths of G. boninense under ammonium citrate, beef extract and urea as nitrogen sources are given in Figure 7 while those under ammonium nitrate and peptone as nitrogen sources are presented in Figure 8. The effects of different nitrogen sources on the mycelial growth of $G$. boninense are presented in Table 4. According to the experimental results, $G$. boninense showed optimum and best mycelial growth on ammonium citrate and ammonium nitrate. Except for urea, peptone and beef extract also facilitated considerable mycelial growth of $G$. boninense (Table 4).

Out of five different nitrogen sources from the present study, the best nitrogen sources for mycelial growth of $G$. boninense are ammonium citrate and ammonium nitrate. Sangeetha and Rawal (2008) reported that ammonium nitrate supported good growth and sporulation the $C$. gloeosporioides, agreeing with the present finding. Deshmukh et al. (2012) found that potassium nitrate as the best nitrogen source for the growth and sporulation of the pathogen C. gloeosporioides.

Similarly, eight strains of $G$. Iucidum showed optimum mycelial growth on ammonium acetate while two strains of G. Iucidum 


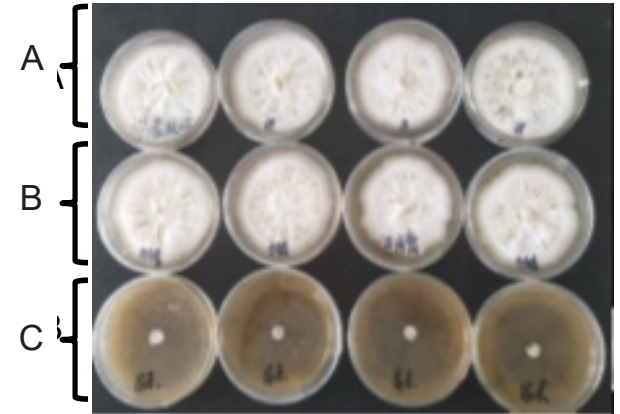

Figure 7 The observational mycelial growths of a Ganoderma boninense under ammonium citrate, $\mathrm{b}$ beef extract and $\mathrm{c}$ urea as nitrogen sources.

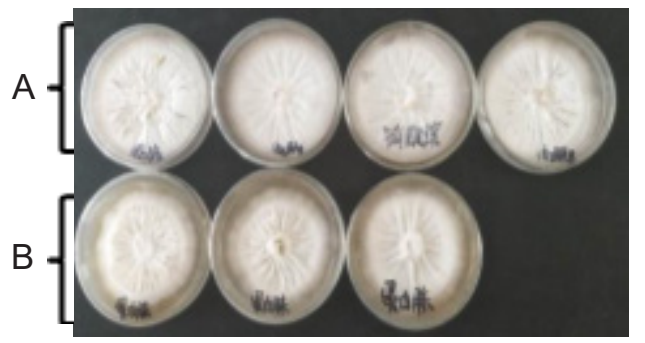

Figure 8 The observational mycelial growths of a Ganoderma boninense under ammonium nitrate and $b$ peptone (one replicate is not available) as nitrogen sources.

Table 4 Effects of different nitrogen sources on the mycelial growth (mean $\pm \mathrm{SE}, \mathrm{cm}$ ) of Ganoderma boninense

\begin{tabular}{|c|c|c|c|c|}
\hline $\begin{array}{l}\text { Nitrogen } \\
\text { sources }\end{array}$ & Day 2 & Day 4 & Day 6 & $\begin{array}{c}\text { My- } \\
\text { celial } \\
\text { growth }\end{array}$ \\
\hline $\begin{array}{l}\text { Peptone } \\
\text { (organic) }\end{array}$ & $\begin{array}{l}1.50 \pm \\
0.02^{\mathrm{a}}\end{array}$ & $\begin{array}{l}3.63 \pm \\
0.01^{\mathrm{b}}\end{array}$ & $\begin{array}{l}5.67 \pm \\
0.07^{\mathrm{bc}}\end{array}$ & ++ \\
\hline $\begin{array}{l}\text { Beef extract } \\
\text { (organic) }\end{array}$ & $\begin{array}{l}1.50 \pm \\
0.02^{\mathrm{a}}\end{array}$ & $\begin{array}{l}3.50 \pm \\
0.01^{\mathrm{b}}\end{array}$ & $\begin{array}{l}6.18 \pm \\
0.03^{c}\end{array}$ & ++ \\
\hline $\begin{array}{l}\text { Ammonium } \\
\text { nitrate (inorganic) }\end{array}$ & $\begin{array}{l}1.50 \pm \\
0.02^{\mathrm{a}}\end{array}$ & $\begin{array}{l}3.50 \pm \\
0.02^{\mathrm{b}}\end{array}$ & $\begin{array}{l}6.75 \pm \\
0.06^{d}\end{array}$ & +++ \\
\hline $\begin{array}{l}\text { Ammonium citrate } \\
\text { (inorganic) }\end{array}$ & $\begin{array}{l}1.50 \pm \\
0.02^{\mathrm{a}}\end{array}$ & $\begin{array}{l}3.50 \pm \\
0.03^{b}\end{array}$ & $\begin{array}{l}6.58 \pm \\
0.05^{d}\end{array}$ & +++ \\
\hline Urea (organic) & $\begin{array}{l}1.50 \pm \\
0.01^{a}\end{array}$ & $\begin{array}{c}1.50 \pm \\
0.01^{a}\end{array}$ & $\begin{array}{c}1.50 \pm \\
0.01^{\mathrm{a}}\end{array}$ & - \\
\hline
\end{tabular}

* Note: The more "+", the better mycelial growth Values sharing a common letter in the post hoc column are not significantly different $(P>0.05)$.

(IUM 757 and 1027) showed no mycelial growth on urea. Therefore, present result indicated that inorganic nitrogen sources (ammonium citrate and ammonium nitrate) enhanced the mycelial growth of
G. boninense, supported by the finding by $G$. lucidum. The present findings are very similar to the observations $\mathrm{V}$. esculenta (Jonathan et al. 2004). Hence, mycelial growth of $G$. boninense was more favorable on the culture media containing inorganic nitrogen sources than organic nitrogen sources.

\section{Effect of Temperature}

After 5 days of inoculation, the observational mycelial growths of $G$. boninense at $15^{\circ} \mathrm{C}, 20^{\circ} \mathrm{C}, 25^{\circ} \mathrm{C}, 30^{\circ} \mathrm{C}$ and $35^{\circ} \mathrm{C}$ are presented in Figure 9 while those at $28{ }^{\circ} \mathrm{C}, 30{ }^{\circ} \mathrm{C}$ and $32{ }^{\circ} \mathrm{C}$ are given in Figure 10 , those at $25^{\circ} \mathrm{C}, 28^{\circ} \mathrm{C}, 30{ }^{\circ} \mathrm{C}$, $32{ }^{\circ} \mathrm{C}$ and $34{ }^{\circ} \mathrm{C}$ are shown in Figure 11 , and those at $34{ }^{\circ} \mathrm{C}, 37{ }^{\circ} \mathrm{C}, 40^{\circ} \mathrm{C}$ and 43 ${ }^{\circ} \mathrm{C}$ are given in Figure 12. Table 5 shows the effects of different temperature on the mycelial growth of $G$. boninense after five days of inoculation.

As shown in Figures 9, 10, 11 and 12, and Table 5, temperature between 25-35 ${ }^{\circ} \mathrm{C}$, after 5 days of inoculation, the mycelia had the fastest growth rate at $30{ }^{\circ} \mathrm{C}$, followed by $25^{\circ} \mathrm{C}$. Ganoderma boninense is not suitable to grow at $15{ }^{\circ} \mathrm{C}, 20^{\circ} \mathrm{C}$, and $35^{\circ} \mathrm{C}$ while there was no sign of mycelium growth at $35^{\circ} \mathrm{C}$.

Figure 11 shows that when temperature at $25^{\circ} \mathrm{C}, 28{ }^{\circ} \mathrm{C}, 30{ }^{\circ} \mathrm{C}, 32{ }^{\circ} \mathrm{C}$ and $34{ }^{\circ} \mathrm{C}$, mycelia had better growth rate at $32{ }^{\circ} \mathrm{C}$, however mycelia grew slowly at $34{ }^{\circ} \mathrm{C}$. As shown in Figure 12 when temperature was set at $34^{\circ} \mathrm{C}, 37^{\circ} \mathrm{C}, 40{ }^{\circ} \mathrm{C}$, $43{ }^{\circ} \mathrm{C}$, mycelia only grew at $34{ }^{\circ} \mathrm{C}$ after 10 days of inoculation. However, the hyphal growth was inhibited at this temperature, growth was slow, and mycelia were sparse. It is observed that temperature at $37{ }^{\circ} \mathrm{C}$ and above resulted in no sign of mycelium growth. As a conclusion, mycelia of $G$. boninense are suitable to grow between 25 and $32{ }^{\circ} \mathrm{C}$, while the optimum temperature is $32{ }^{\circ} \mathrm{C}$. Temperature at $34{ }^{\circ} \mathrm{C}$ and above will inhibit the growth 


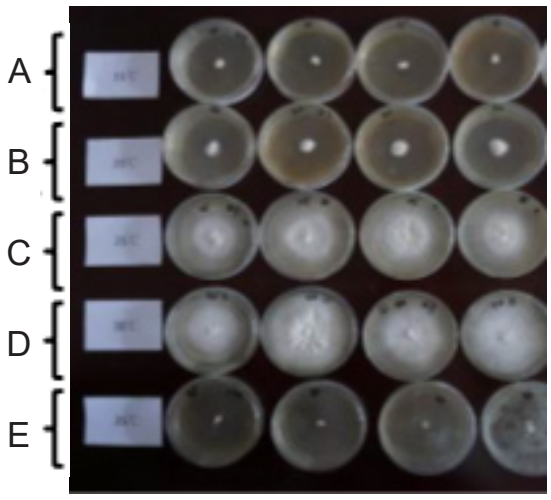

Figure 9 The observational mycelial growths of Ganoderma boninense at a $15^{\circ} \mathrm{C}, \mathrm{b} 20^{\circ} \mathrm{C}, \mathrm{c} 25^{\circ} \mathrm{C}$, d $30^{\circ} \mathrm{C}$ and e $35^{\circ} \mathrm{C}$, after 5 days of inoculation.

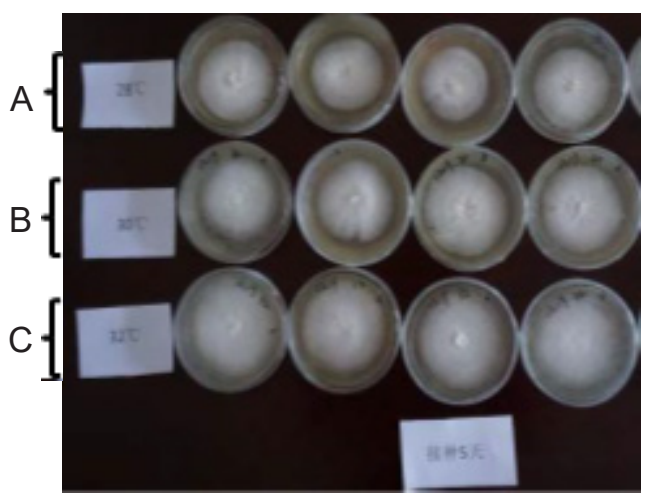

Figure 10 The observational mycelial growths of Ganoderma boninense at a $28^{\circ} \mathrm{C}, \mathrm{b} 30^{\circ} \mathrm{C}$ and c $32{ }^{\circ} \mathrm{C}$, after 5 days of inoculation.

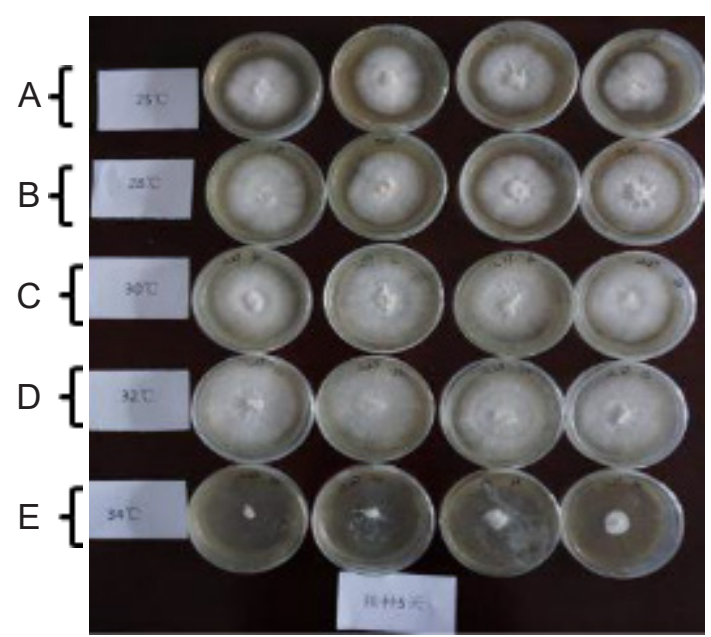

Figure 11 The observational mycelial growths of Ganoderma boninense at a $25^{\circ} \mathrm{C}$, b $28^{\circ} \mathrm{C}, \mathrm{c} 30^{\circ} \mathrm{C}$, d $32{ }^{\circ} \mathrm{C}$ and e $34^{\circ} \mathrm{C}$, after 5 days of inoculation.

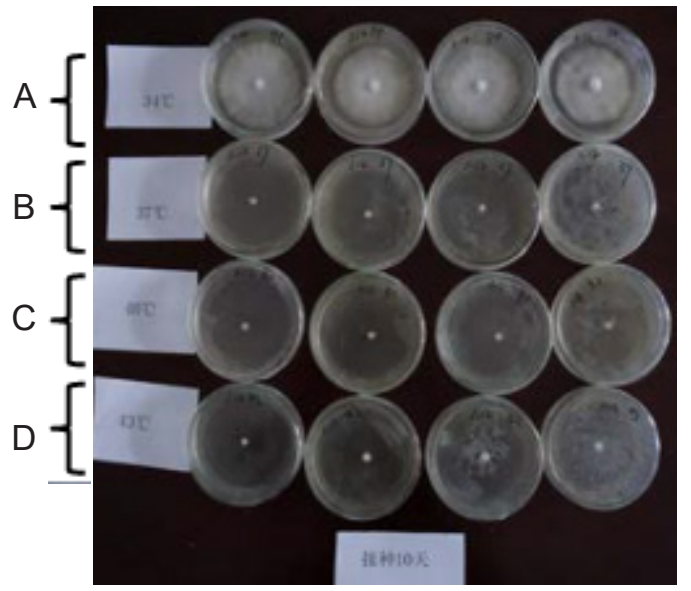

Figure 12 The observational mycelial growths of Ganoderma boninense at a $34^{\circ} \mathrm{C}$, b $37^{\circ} \mathrm{C}$, c 40 ${ }^{\circ} \mathrm{C}$ and $\mathrm{d} 43^{\circ} \mathrm{C}$, after 5 days of inoculation.

Table 5 The effects of different temperatures on the mycelial growth RATE (mean $\pm \mathrm{SE}, \mathrm{cm} /$ day) of Ganoderma boninense after five days of inoculation

\begin{tabular}{cccc}
\hline Number & Temperature & $\begin{array}{c}\text { Growth rate } \\
\left(\mathrm{cm} \mathrm{g}^{-1}\right)\end{array}$ & $\begin{array}{c}\text { Growth } \\
\text { potential }\end{array}$ \\
\hline 1 & $15^{\circ} \mathrm{C}$ & $0.22 \pm 0.01^{\mathrm{a}}$ & + \\
2 & $20^{\circ} \mathrm{C}$ & $0.52 \pm 0.02^{\mathrm{b}}$ & + \\
3 & $25^{\circ} \mathrm{C}$ & $0.79 \pm 0.03^{\mathrm{c}}$ & +++ \\
4 & $28^{\circ} \mathrm{C}$ & $0.83 \pm 0.04^{\mathrm{c}}$ & +++ \\
5 & $30^{\circ} \mathrm{C}$ & $0.88 \pm 0.09^{\mathrm{c}}$ & ++++ \\
6 & $32^{\circ} \mathrm{C}$ & $0.89 \pm 0.07^{\mathrm{c}}$ & ++++ \\
7 & $34^{\circ} \mathrm{C}$ & $0.30 \pm 0.01^{\mathrm{a}}$ & ++ \\
& & $\begin{array}{c}\text { No } \\
\text { (3) }\end{array}$ & $\begin{array}{c}\text { um growth } \\
\text { mycelium } \\
\text { growth }\end{array}$ \\
\hline
\end{tabular}

* Note: The more "+", the better mycelial growth Values sharing a common letter in the post hoc column are not significantly different $(P>0.05)$.

of mycelia. Previously, $\mathrm{Ho}$ and Nawawi (1985) reported the optimum temperature for mycelial growth of $G$. boninense from Peninsular Malaysia were between 27-29 ${ }^{\circ} \mathrm{C}$ and significantly poorer at $21^{\circ} \mathrm{C}$.

Jonathan and Fasidi (2003) found that Psathyrella atroumbonatai grew fairly well within the temperature range of between 
25 and $35^{\circ} \mathrm{C}$. the best mycelial growth $\mathrm{G}$. lucidum was found at $30{ }^{\circ} \mathrm{C}$. Shim et al. (2003) reported that the mycelial growth of Paecilomyces fumosoroseus was favourable at the range of between 20 and $25^{\circ} \mathrm{C}$ and had been expedited in proportion to the rise of temperature. However, the mycelial growth appeared to be inhibited at the temperature higher than $30^{\circ} \mathrm{C}$. Jonathan et al. (2004) also reported that the growth of Schizophyllum commune was inhibited at 45 and $50{ }^{\circ} \mathrm{C}$. This could be attributable to the denaturation and inactivation of important enzymes which catalyse metabolic processes of the experimented fungus. Therefore, similar explanation can be provided for temperature

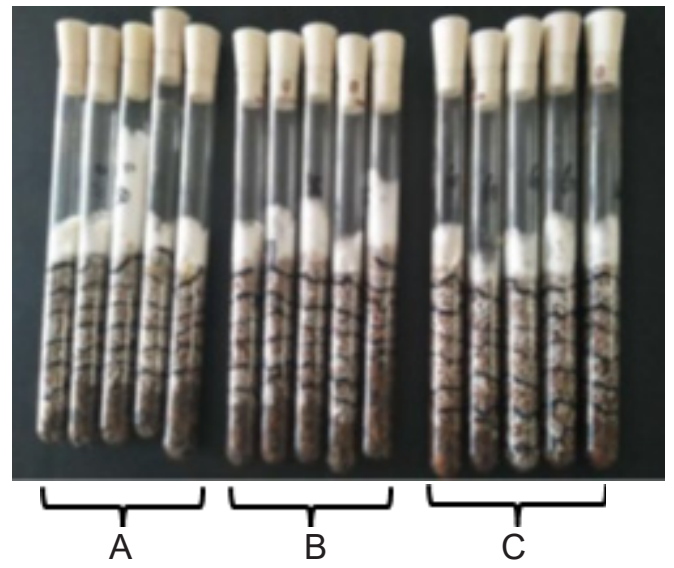

Figure 13 The observational mycelial growths of Ganoderma boninense under humidity of a $50 \%$, b $55 \%$ and c $60 \%$. at $34{ }^{\circ} \mathrm{C}$ and above that inhibited the mycelial growth of $G$. boninense.

\section{Effect of Humidity}

The observational mycelial growths of $G$. boninense under humidity of $50 \%$, $55 \%$ and $60 \%$ are presented in Figure 13 while those under humidity of $65 \%$ and $70 \%$ are given in Figure 14 . The effects of different humidity on the mycelial growth of $G$. boninense are presented in Table 4. Therefore, from Figures 13 and 14, and Table 6, it shows that the best humidity for mycelial growth of $G$. boninense is between $50-60 \%$. There is limited reported study on the effect of humidity on the mycelial growth of $G$. boninense.

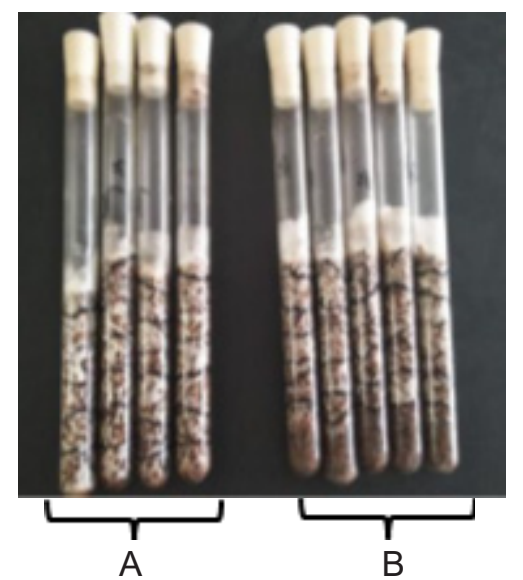

Figure 14 The observational mycelial growths of Ganoderma boninense under humidity of a $65 \%$; b one replicate is not available) and $70 \%$.

Table 6 The effects of different humidity on the mycelial growth (mean \pm SE, $\mathrm{cm}$ ) of Ganoderma boninense

\begin{tabular}{cccccccc}
\hline$\%$ & Day 2 & Day 4 & Day 6 & Day 8 & Day 10 & Day 12 $\begin{array}{c}\text { Mycelia } \\
\text { growth }\end{array}$ \\
\hline 50 & $0.66 \pm 0.02^{\mathrm{a}}$ & $1.80 \pm 0.05^{\mathrm{a}}$ & $2.72 \pm 0.02^{\mathrm{a}}$ & $3.78 \pm 0.04^{\mathrm{a}}$ & $4.82 \pm 0.05^{\mathrm{a}}$ & $6.02 \pm 0.06^{\mathrm{a}}$ & +++ \\
55 & $0.78 \pm 0.03^{\mathrm{b}}$ & $1.96 \pm 0.03^{\mathrm{a}}$ & $2.96 \pm 0.05^{\mathrm{ac}}$ & $3.94 \pm 0.05^{\mathrm{a}}$ & $5.04 \pm 0.04^{\mathrm{a}}$ & $6.12 \pm 0.05^{\mathrm{a}}$ & +++ \\
60 & $0.90 \pm 0.02^{\mathrm{c}}$ & $2.22 \pm 0.01^{\mathrm{b}}$ & $3.38 \pm 0.05^{\mathrm{cd}}$ & $4.64 \pm 0.04^{\mathrm{b}}$ & $6.06 \pm 0.05^{\mathrm{b}}$ & $7.02 \pm 0.04^{\mathrm{b}}$ & +++ \\
65 & $0.74 \pm 0.03^{\mathrm{b}}$ & $2.26 \pm 0.02^{\mathrm{b}}$ & $3.60 \pm 0.06^{\mathrm{d}}$ & $4.98 \pm 0.02^{\mathrm{b}}$ & $6.40 \pm 0.04^{\text {cd }}$ & $7.64 \pm 0.06^{\mathrm{c}}$ & ++ \\
70 & $0.90 \pm 0.02^{\mathrm{c}}$ & $2.30 \pm 0.04^{\mathrm{b}}$ & $3.90 \pm 0.07^{\mathrm{e}}$ & $6.10 \pm 0.05^{\mathrm{c}}$ & $6.96 \pm 0.07^{\mathrm{d}}$ & $8.30 \pm 0.05^{\mathrm{d}}$ & ++ \\
\hline
\end{tabular}

* Note: The more "+", the better mycelial growth

Values sharing a common letter in the post hoc column are not significantly different $(P>0.05)$. 


\section{CONCLUSIONS}

In the present in vitro study, fruiting bodies of $G$. boninense were collected from oil palm plantation in Malaysia. Isolation and subculture were done to get the pure culture of $G$. boninense. The effects of different carbon sources, nitrogen sources, humidity, temperature and medium with different $\mathrm{pH}$ regimes on the mycelial growth of $G$. boninense were investigated. In medium with $83 \%$ potatoes, mycelia of $G$. boninense could be able to grow in $\mathrm{pH}$ regimes of $5,6,7,8,9$ and 10 . In $\mathrm{pH} 5$, mycelia had the best growth rate. Therefore, the optimum $\mathrm{pH}$ for mycelia growth of $G$. boninense in medium with $83 \%$ potatoes is $\mathrm{pH} 5$. However, mycelia grew well in medium with $75 \%$ lignocellulosic materials of $\mathrm{pH} 4$. This indicated better mycelia color and growth rate in $\mathrm{pH}$ 4. Therefore, the ideal $\mathrm{pH}$ regimes for the mycelial growth were 4-5.

The results showed that the best carbon sources for the mycelial growth of $G$. boninense were glucose and fructose, while the best nitrogen sources were ammonium citrate and ammonium nitrate. The optimum humidity for the mycelia growth was between $50-60 \%$. It is suitable to grow between 25 and $32{ }^{\circ} \mathrm{C}$, while the optimum temperature is $32{ }^{\circ} \mathrm{C}$. Temperature at $34{ }^{\circ} \mathrm{C}$ and above will inhibit the growth of mycelia.

This optimal nutritional conditions and environment can be fully utilized as a guideline for Ganoderma's prevention study and for spawn production in the future. Hence, the use of nutritional conditions with fructose and glucose as carbon sources, with ammonium citrate and ammonium nitrate bases, and slightly acidic soils can promote the growth of $G$. boninense in Malaysia.

\section{REFERENCES}

Adejoye OD, Adebayo-Tayo BC, Ogunjobi AA, Afolabi OO. 2007. Physico-chemical studies on Schizophyllum commune (Fries), a Nigerian edible fungus. World Appl Sci J. 2:73-76.

Akinyele BJ, Adetuyi FC. 2005. Effect of agrowastes, $\mathrm{pH}$ and temperature variation on the growth of Volvariella volvacea. Afr J Biotech. 4:1390-1395.

Alexander A, Sipaut CS, Dayou J, Chong KP. 2017. Oil palm roots colonisation by Ganoderma boninense: An insight study using scanning electron microscopy. J Oil Palm Res. 29(2):262-266.

Ariffin D, Idris AS. 1992. The Ganoderma selective medium (GSM). PORIM Information Series No. 8: 2pp.

Bhojwani SS, Rajdan MK. 1996. Plant tissue culture: theory and Practice, a revised Edition. Netherland (NL): Elsevier. pp. 4748.

Chandra A, Purkayastha RP. 1977. Physiological studies on Indian mushrooms. Trans Br Mycol Soc. 69:63-70.

Daza A, Manjón JL, Camacho M, Romero De La Osa L, Aguilar A, Santamaría C. 2016. Effect of carbon and nitrogen sources, $\mathrm{pH}$ and temperature on in vitro culture of several isolates of Amanita caesarea (Scop.:Fr.) Pers. Mycorrhiza. 16(2):133-136.

De paiva neto VB, Otoni WC. 2003. Carbon sources and their osmotic potential in plant tissue culture, does it matter? Sci horticulturae. 97:193-202.

Deshmukh AJ, Mehta BP, Sabalpara AN, Patil VA. 2012. In vitro effect of various nitrogen, carbon sources and $\mathrm{pH}$ regimes on the growth and sporulation of Colletotrichum gloeosporioides Penz. and Sacc causing anthracnose of Indian bean. J Biopesticides. 5:46-49. 
Fasola TR, Gbolagade JS, Fasidi IO. 2007. Nutritional requirements of Volvariella speciosa (Fr. Ex. Fr.) Singer, a Nigerian edible mushroom. Food Chem. 100:904-908.

Fowotade SA, Yusof NA, Abdullah J, Sulaiman Y, Abd Rahman SF. 2019. Enhanced electrochemical sensing of secondary metabolites in oil palms for early detection of Ganoderma boninense based on novel nanoparticle-chitosan functionalized multi-walled carbon nanotube platform. Sensing Bio Sens Res. 23:1-8. DOI: https://doi. org/10.1016/j.sbsr.2019.100274.

Garraway OM, Evans CR. 1984. Fungal Nutrition and Physiology. New York (US): John Wiley and Sons.

Goh YK, Marzuki NF, Tan SY, Tan SS, Tung HJ, Goh YK, Goh KJ. 2016. Experimental mixture design as a tool to optimize the growth of various Ganoderma species cultivated on media with different sugars. Mycology 7(1):36-44.

Griffin DH. 1994. Fungal Physiology. 2nd edition. New York (US): Wiley Liss. pp. 130-157.

Ho YW, Nawawi A. 1985. Ganoderma boninense Pat. from basal stem rot of oil palm (Elaeis guineensis) in Peninsular Malaysia. Pertanika. 8(3):425-428.

Hushiarian R, Yusof NA, Dutsm SW. 2013. Detection and control of Ganoderma boninense: strategies and perspectives. SpringerPlus. 2(1):1-12.

Idris AS, Mohd Shukri I, Norman K, Choo YM, Kushairi A, Hanafi MM, Mohd Nawawai W, Zaafar MD. 2015. Chemical fertiliser GanoCare ${ }^{\mathrm{TM}}$ as preventive treatment in controlling Ganoderma disease of oil palm. MPOB Information Series No. 564: 4 pp.

Idris AS, Mohd Shukri I, Norman K, Kushairi A, Choo YM, Hanafi MM, Talib R, Md Sofian Md Y. 2014. GanoCare ${ }^{\mathrm{TM}}$ reducing risk of Ganoderma infection in oil palm. MPOB Information Series No. 545: 4 pp.

Itoo ZA, Reshi ZA. 2014. Effect of different nitrogen and carbon sources and concentrations on the mycelial growth of ectomycorrhizal fungi under in-vitro conditions. Scandinavian J Forest Res. 29(7):619-628.

Jayasinghe $\mathrm{C}$, Imtiaj $\mathrm{A}$, Hur $\mathrm{H}$, Woo Lee GW, Lee TS, Lee UY. 2008. Favorable culture conditions for mycelial growth of Korean wild strains in Ganoderma lucidum. Mycobiol. 36(1):28-33.

Jeong YT, Jeong SC, Yang BK, Islam R, Song $\mathrm{CH}$. 2009. Optimal culture conditions for mycelial growth and exo-polymer production of Ganoderma applanatum. Mycobiol. 37(2):89-93.

Jo WS, Cho YJ, Cho DH, Park SD, Yoo YB, Seok SJ. 2009. Culture conditions for the mycelial growth of Ganoderma applanatum. Mycobiol. 37(2):94-102.

Jonathan SG, Fasidi IO, Ajayi EJ. 2004. Physico-chemical studies on Volvariella esculent Mass (Singer), a Nigerian edible fungus. Food Chem. 85:339342.

Jonathan SG, Fasidi IO. 2003. Studies on Psathyrella atroumbonatai (Pegler), a Nigerian edible fungus. Food Chem. 81:481-484.

Lazarević J, Stojičić D, Keča N. 2016. Effects of temperature, $\mathrm{pH}$ and carbon and nitrogen sources on growth of in vitro cultures of ectomycorrhizal isolates from Pinus heldreichii forest. Forest Syst. 25(1):e048.

Li P, Wang H, Liu G, Li X, Yao J. 2011. The effect of carbon source succession on laccase activity in the co-culture process of Ganoderma lucidum and a yeast. Enzyme Microb Technol. 48(1):1-6.

Lilleskov E, Hobbie EA, Fahey TJ. 2002. Ectomycorrhizal fungal taxa differing in response to nitrogen deposition also 
differ in pure culture organic nitrogen use and natural abundance of nitrogen isotopes. New Phytol. 159:219-231.

Lipavska H, Konradova H. 2004. Somatic embryogenesis in conifers: The role of carbohydrate metabolism. In vitro Cell Dev Biol Plant. 40:23-30.

Mamoun M, Olivier J. 1991. Effect of carbon and nitrogen sources on the in vitro growth of Tuber melsnosporum (Vitt). Application to mycelial biomass production. Agronomie. 11(6):521-527.

Panchal RR, Raol BV. 2007. In vitro effect of various carbon and nitrogen sources on vegetative growth of Fusarium moniliforme Sheldon Var. Subglutinan isolated from wilted sugar cane fields. Asian J Microbiol Biotechnol Environ Sci. 9(1):133-138.

Papaspyridi L, Sbokov E, Christakopoulos P. 2012. Effect of carbon and nitrogen sources on the production of dietary fibres and glucans by submerged cultures of two greek mushroom species, Ganoderma australe and Pleurotus ostreatus. Acta Alimentaria. 41(2):200210.

Peng L, Li J, Liu Y, Xu Z, Wu J-Y, Ding Z, Gu Z, Zhang L, Shi G. 2016. Effects of mixed carbon sources on galactose and mannose content of exopolysaccharides and related enzyme activities in Ganoderma lucidum. RSC Advances. 6(45):39284-39291.

Sangeetha CG, Rawal RD. 2008. Nutritional studies of Colletotrichum gloeosporioides (Penz.) Penz. and Sacc. The incitant of mango anthracnose. World J Agricul Sci. 4(6):717-720.
Shim SM, Lee KR, Kim SH, Im KH, Kim JW, Lee UY, Shim JO, Lee MW, Lee TS. 2003. The optimal culture conditions affecting the mycelial growth and fruiting body formation of Paecilomyces fumosoroseus. Mycobiol. 31:214220.

Songulashvili GG, Elisashvili V, Wasser SP, Hadar Y, Nevo E. 2008. Effect of the carbon source and inoculum preparation method on laccase and manganese peroxidase production in submerged cultivation by the medicinal mushroom Ganoderma lucidum (W. Curt.: Fr.) P. Karst. (Aphyllophoromycetideae). Int J Med Mushrooms. 10(1):79-86.

Swetha Prasuna VN, Srinivas B. 2016. Role of different carbon sources on In vitro micropropagation of Oxalis corniculata (L.). Int J Pharm Biol Sci. 6(3):98104.

Tan JS, Lee YP, Sulaiman S, Camus-Kulandaivelu L, Klopp $\mathrm{C}$, Mercière $\mathrm{M}$, Breton F, Durand-Gasselin T, Alwee SSRS. 2018. The route to the development of basal stem rot resistance in oil palm (Elaeis guineensis) via the discovery of lignin degradation process in the pathogen Ganoderma boninense. Acta Horticul. 1205:359-370.

Yaseen M, Ahmad T, Sablok G, Standardi A, Hafiz IA. 2013. Review: role of carbon sources for in vitro plant growth and development. Mol Biol Rep. 40(4):2837-2849. 